\title{
Consumption Pattern of Selected Elderly
}

\author{
Varsha Zanvar $^{1 *}$ and Madhuri Revanwar ${ }^{2}$ \\ ${ }^{1}$ Department of Home Science, Shri Yoganand Swami Arts College, \\ Basmath, Hingoli (MS), India \\ ${ }^{2}$ SMS, KVK, Sagroli District, Nanded, India \\ *Corresponding author
}

\section{A B S T R A C T}

\section{Keywords}

Height weight, Hip circumference,

Waist

circumference,

Body mass index

\section{Article Info}

Accepted:

12 November 2019

Available Online:

10 December 2019
Present study was conducted to assess the nutritional status of 600 elderly populations residing in urban (200), rural (200) and tribal area (200) of Nanded district of Marathwada region of Maharashtra state, India. Anthropometric status of selected elderly was determined by recording height $(\mathrm{cm})$, weight $(\mathrm{kg})$, hip circumference $(\mathrm{cm})$, waist circumference $(\mathrm{cm})$ and body mass index was calculated using values of height and weight. On the basis of BMI, selected subjects were categorised under different grades of under nutrition. Daily food intake of each selected elderly was recorded with the help of two days dietary recall method and weighment method. By using food consumption table of ICMR the nutrient intake of the elderly was calculated. Food intake was compared with balanced diet and nutrient intake was compared with the ICMR recommended dietary allowances (ICMR 2012) to find out the percent adequacy in consumption. Result revealed that the values for height of vegetarian and non-vegetarian elderly from urban, rural and tribal area ranged from $150.87 \pm 7.97$ to $161.59 \pm 7.95 \mathrm{~cm}$. While weight ranged from $44.53 \pm 8.57$ to $60.75 \pm 10.91 \mathrm{~kg}$. More percent $(28 \%)$ of elderly from non vegetarian food habit were found to be underweight. On the contrary, more percent of vegetarian elderly subjects were overweight than non vegetarian elderly. Selected vegetarian elderly subjects were consuming significantly more cereals $(230.88 \pm 81.50 \mathrm{gm})$. Highest percent adequacy was noted for sugar and jaggery in both groups. Intake of different nutrients was found to be more among vegetarian elderly. Highest percent adequacy was noted among vegetarian elderly for fat (112.84\%) and lowest percent adequacy was noted among non vegetarian elderly for calcium $(26.95 \%)$.

\section{Introduction}

India has acquired the label of aging nation with 7.7 percent of its population being more than 60 years old. There has been a sharp increase in the proportion of elderly population in India as a result of demographic transition (Pai, 2011). The global number of the elderly is projected to rise from an estimated 524 million in 2010 to nearly 1500 million in 2050 with most of this increase in developing countries (Gandhi et al., 2018). In the fullest biological sense it designates the sequences of mental and physical changes that 
begin at conception and end at death. Anthropometric evaluation is an essential feature of geriatric nutritional evaluation for determining malnutrition (Garcia et al., 2007). The functional capacity and health of the elderly depend to a greater extent on their nutritional status and food security. Average diet and nutrient intake of elderly were found to be deficient as compared to recommended daily allowances suggested for elderly. Diet plays an important role in the aging process. Older people have different eating pattern than their younger counterparts. Many physical problems of the older people may be prevented or cured by proper nutrition. Even in the best of circumstances, aging weakens the immune system. Insufficient calories, lack of protein and micronutrient deficiencies in the elderly further weaken their immunity and expose them to infection that may reduce absorption of essential nutrients, thereby compounding the cycle of undernutrition and infection.

\section{Materials and Methods}

Present study was conducted to assess nutritional status of elderly population having different food habits residing in Nanded district of Marathwada region of Maharashtra state, India. Random sampling technique was used for selection of samples and 200 each were selected from urban, rural and tribal areas. Out of total elderly 375 were vegetarian while 225 were non vegetarian by their food habits. Anthropometric measurements like weight, height was recorded by using standard methods and procedure (Jelliffee, 1966) and BMI was calculated by given formula (ICMR, 1986). Food intake was assessed by two day recall method and weighment method. By using food consumption table of ICMR (Gopalan et al., 2004). The nutrient intake of the elderly was calculated. To find out the percent adequacy food and nutrient intake of the elderly was compared with the balanced diet and recommended dietary allowances (ICMR, 2012).

\section{Results and Discussion}

The anthropometric measurements of selected elderly subjects with respect to area and food habits depicted in Table 1. The values for height of vegetarian and non-vegetarian elderly from urban, rural and tribal area ranged from $150.87 \pm 7.97$ to $161.59 \pm 7.95 \mathrm{~cm}$. While weight ranged from $44.53 \pm 8.57$ to $60.75 \pm 10.91 \mathrm{~kg}$. The body mass index exhibited range from $19.40 \pm 2.64$ to $23.14 \pm 2.80$. Further it was noted that range of waist circumference, hip circumference and waist hip ratio was $69.11 \pm 8.35$ to $86.46 \pm 9.56$, $76.36 \pm 9.21$ to $92.91 \pm 10.18$ and $0.89 \pm 0.04$ to $0.93 \pm 0.03$ respectively. However, the mean height (161.59 \pm 7.95$)$ and weight $(60.75 \pm 10.91)$ of non vegetarian elderly was noted greater than vegetarian elderly subjects. When compared in between three areas, values were noted more among urban elderly subjects and lowest among tribal elderly subjects. Calculated BMI was more among vegetarian elderly from urban area $(23.14 \pm 2.88)$ as compared to elderly of other two areas. In case of waist circumference $(86.46 \pm 9.56)$ and hip circumference $(92.91 \pm 10.18)$, also values were found higher among non vegetarian elderly from urban area as compared to other two areas. On the whole, the highest values for almost all the measurements were noted in urban nonvegetarian elderly subjects. While lowest values were noted in tribal vegetarian elderly. The difference between vegetarian and nonvegetarian elderly for all anthropometric values in three residential areas were non significant statistically. This could be due to rare consumption of non-vegetarian food.

Table 2 revealed the data on prevalence of under nutrition among selected elderly on the basis of food habits. It is evident from the 
table that, almost equal percent of elderly (61.6 and $61.77 \%$ ) were found to be normal among two groups. While more percent (28\%) of elderly from non vegetarian food habit were found to be underweight. On the contrary, more percent of vegetarian elderly subjects were overweight than non vegetarian elderly. Even majority of tribal $(60 \%)$ were reported that they were consuming non vegetarian food, but it was occasionally. Hence the impact of food habit was not remarkable.

Table 3 illustrates the average food intake by selected vegetarian and non-vegetarian elderly subjects. Selected vegetarian elderly subjects were consuming significantly more cereals $(230.88 \pm 81.50$ gm.) than non-vegetarian elderly subjects (198.25 \pm 68.29 gm.). Vegetarian elderly were consuming $20.50 \pm 29.20$ gm. green leafy vegetables, $38.10 \pm 33.38 \mathrm{gm}$. roots and tubers, $23.68 \pm 32.12 \mathrm{gm}$. other vegetables, $29.21 \pm 36.37 \mathrm{gm}$. fruits, $11.67 \pm 5.68 \mathrm{gm}$. fats and oil and $72.93 \pm 60.16 \mathrm{gm}$. milk and milk products which was significantly more than that of non-vegetarian elderly subjects. Whereas, pulses $(28.80 \pm 13.80 \mathrm{gm}$.) and sugar and jaggery (17.71 $\pm 7.41 \mathrm{gm}$.) was found to be consumed more by non-vegetarian elderly subjects than vegetarian $(26.95 \pm 14.15$ and $15.21 \pm 8.04 \mathrm{gm}$. respectively). Overall it can be stated that, except pulses and fruits statistically significant difference was noted among consumption of different food stuffs. Non-vegetarian elderly consumed nonvegetarian foods rarely and followed vegetarian diet. Hence the contradictory result may be noticed.

The percent adequacy of food intake as influenced by food habits is depicted in Table 4. It is evident from the table that, the percent adequacy ranged from 14.04 percent (roots and tubers) to 86.54 percent (cereals) for vegetarian and 5.95 percent (roots and tubers) to 88.55 percent (sugar and jaggery) for nonvegetarian elderly subjects. In vegetarian, highest adequacy was recorded for cereals while in non-vegetarians it was recorded for sugar and jaggery. Whereas, least adequacy was recorded for consumption of roots and tubers in both groups. Whereas, 60 to 87 percent adequacy was noted for cereals and pulses among vegetarian and non vegetarian elderly. However, highest percent adequacy was noted for sugar and jaggery in both groups.

Table 5 illustrates the nutrient intake of elderly of different food habits. It is inferred from the table that, intake of different nutrients was found to be more among vegetarian elderly i.e. protein $(35.11 \pm 11.97$ gm), carbohydrate $(217.46 \pm 67.43 \mathrm{gm}$.), fat $(22.70 \pm 10.18$ gm.), energy (1227.23 \pm 397.35 kcal.), iron (12.82 \pm 6.49 mg.), calcium (336.10 $\pm 182.61 \quad$ mg.), Phosphorus (794.38 $\pm 312.28 \mathrm{mg}$.$) , and vitamin C$ (28.47 $\pm 26.13 \mathrm{mg}$.) than elderly belonging to non vegetarian food habits. The corresponding values for all nutrient intake by elderly of non vegetarian group were 29.74 $\pm 9.95 \mathrm{gm}$., $189.63 \pm 56.39 \quad$ gm., $16.01 \pm 7.66 \quad$ gm., $1026.97 \pm 327.08$ kcal., $10.43 \pm 5.10 \mathrm{mg}$., $215.55 \pm 154.91 \mathrm{mg}$., $651.73 \pm 265.19 \mathrm{mg}$., $16.59 \pm 18.50 \mathrm{mg}$. respectively. It may be due to non vegetarian elderly were consuming non vegetarian foods very rarely. They only reported their dietary pattern as non vegetarian, but consuming it very occasionally.

Percent adequacy of different nutrient as per food habits of elderly subjects is given in Table 6. It is indicated in the table that, percent adequacy of all the nutrients was found to be lowest in non vegetarian elderly subjects as compared to vegetarian elderly. 
Table.1 Anthropometric measurements of selected elderly as per different food habits and area

\begin{tabular}{|c|c|c|c|c|c|c|c|c|c|}
\hline \multirow[t]{2}{*}{$\begin{array}{c}\text { Anthropometric } \\
\text { measurements }\end{array}$} & \multicolumn{3}{|c|}{$\begin{array}{c}\text { Urban } \\
(\text { Mean } \pm \text { SD })\end{array}$} & \multicolumn{3}{|c|}{$\begin{array}{c}\text { Rural } \\
(\text { Mean } \pm \text { SD })\end{array}$} & \multicolumn{3}{|c|}{$\begin{array}{c}\text { Tribal } \\
(\text { Mean } \pm \text { SD })\end{array}$} \\
\hline & $\begin{array}{l}\text { Vegetarian } \\
(n=155)\end{array}$ & $\begin{array}{c}\text { Non } \\
\text { vegetarian } \\
(n=45)\end{array}$ & $\begin{array}{c}\mathbf{Z} \\
\text { value }\end{array}$ & $\begin{array}{l}\text { Vegetarian } \\
(n=143)\end{array}$ & $\begin{array}{c}\text { Non } \\
\text { vegetarian } \\
(n=57)\end{array}$ & $\begin{array}{c}\mathrm{Z} \\
\text { value }\end{array}$ & $\begin{array}{l}\text { Vegetarian } \\
(n=78)\end{array}$ & $\begin{array}{c}\text { Non } \\
\text { vegetarian } \\
(\mathrm{n}=122)\end{array}$ & $\begin{array}{c}\mathrm{Z} \\
\text { value }\end{array}$ \\
\hline Height (cm) & $159.44 \pm 14.37$ & $161.59 \pm 7.95$ & NS & $\begin{array}{c}156.58 \pm 14.5 \\
3\end{array}$ & $158.36 \pm 5.97$ & NS & $150.87 \pm 7.97$ & $151.10 \pm 7.95$ & NS \\
\hline Weight (kg) & $59.69 \pm 9.18$ & $60.75 \pm 10.91$ & NS & $52.67 \pm 10.31$ & $52.59 \pm 8.47$ & NS & $44.53 \pm 8.57$ & $46.06 \pm 9.68$ & NS \\
\hline BMI(kg/m2) & $23.14 \pm 2.88$ & $22.57 \pm 5.41$ & NS & $21.15 \pm 3.48$ & $20.98 \pm 3.16$ & $\mathrm{NS}$ & $19.40 \pm 2.64$ & $19.56 \pm 2.49$ & NS \\
\hline $\begin{array}{c}\text { Waist } \\
\text { circumference }(\mathrm{cm})\end{array}$ & $84.78 \pm 7.29$ & $86.46 \pm 9.56$ & NS & $82.40 \pm 9.91$ & $82.05 \pm 7.85$ & $\mathrm{NS}$ & $69.65 \pm 10.03$ & $69.11 \pm 8.35$ & NS \\
\hline $\begin{array}{c}\text { Hip } \\
\text { circumference }(\mathrm{cm})\end{array}$ & $90.47 \pm 9.00$ & $92.91 \pm 10.18$ & NS & $88.57 \pm 11.23$ & $87.38 \pm 10.05$ & $\mathrm{NS}$ & $76.93 \pm 10.25$ & $76.36 \pm 9.21$ & NS \\
\hline Waist hip ratio & $0.93 \pm 0.03$ & $0.92 \pm 0.04$ & NS & $0.92 \pm 0.04$ & $0.93 \pm 0.03$ & NS & $0.89 \pm 0.04$ & $0.90 \pm 0.04$ & NS \\
\hline
\end{tabular}

NS- Non significant

Table.2 Prevalence of under nutrition among selected elderly on the basis of food habits

\begin{tabular}{|c|c|c|}
\hline \multicolumn{1}{|c|}{ BMI } & $\begin{array}{c}\text { Vegetarian }(\boldsymbol{\%}) \\
(\mathbf{n}=\mathbf{3 7 5})\end{array}$ & $\begin{array}{c}\text { Non vegetarian }(\boldsymbol{\%}) \\
(\mathbf{n}=\mathbf{2 2 5})\end{array}$ \\
\hline Underweight $(<\mathbf{1 8 . 5})$ & $83(22.13)$ & $63(28)$ \\
\hline Normal(18.5 $\mathbf{- 2 5})$ & $231(61.6)$ & $139(61.77)$ \\
\hline Overweight $(>\mathbf{2 5})$ & $61(16.26)$ & $23(10.22)$ \\
\hline
\end{tabular}

Figures in parenthesis indicates percentages 
Table.3 Average food intake by the selected elderly subjects from different food habits

\begin{tabular}{|c|c|c|c|}
\hline Food groups (gm) & $\begin{array}{c}\text { Vegetarian } \\
(\mathbf{n = 3 7 5})\end{array}$ & $\begin{array}{c}\text { Non vegetarian } \\
(\mathbf{n = 2 2 5})\end{array}$ & Z value \\
\hline Cereals & $230.88 \pm 81.50$ & $198.25 \pm 68.29$ & $5.27^{* *}$ \\
\hline Pulses & $26.95 \pm 14.15$ & $28.80 \pm 13.80$ & $\mathrm{NS}$ \\
\hline Green leafy Vegetables & $20.50 \pm 29.20$ & $11.67 \pm 23.91$ & $4.03^{* *}$ \\
\hline Roots and tubers & $38.10 \pm 33.38$ & $29.90 \pm 33.86$ & $2.89^{* *}$ \\
\hline Other vegetables & $23.68 \pm 32.12$ & $10.48 \pm 23.11$ & $5.84^{* *}$ \\
\hline Fruits & $29.21 \pm 36.37$ & $25.48 \pm 33.37$ & $\mathrm{NS}$ \\
\hline Fats and oil & $11.67 \pm 5.68$ & $8.94 \pm 4.11$ & $7.18^{* *}$ \\
\hline Milk and milk products & $72.93 \pm 60.16$ & $32.55 \pm 41.61$ & $9.70^{* *}$ \\
\hline Sugar and jiggery & $15.21 \pm 8.04$ & $17.71 \pm 7.41$ & $3.9 * *$ \\
\hline
\end{tabular}

**- Significant at $1 \%$, NS- Non significant

Table.4 Percent adequacy of food intake by the selected elderly from different food habits

\begin{tabular}{|c|c|c|}
\hline Food groups $(\mathbf{g m})$ & $\begin{array}{c}\text { Vegetarian } \\
(\mathbf{n = 3 7 5})\end{array}$ & $\begin{array}{c}\text { Non vegetarian } \\
(\mathbf{n = 2 2 5})\end{array}$ \\
\hline Cereals & 86.54 & 69.71 \\
\hline Pulses & 61.50 & 63.56 \\
\hline Green leafy Vegetables & 40.91 & 23.34 \\
\hline Roots and tubers & 14.04 & 5.95 \\
\hline Other vegetables & 38.04 & 29.90 \\
\hline Fruits & 14.59 & 12.74 \\
\hline Fats and oil & 24.24 & 10.85 \\
\hline Milk and milk products & 53.57 & 39.84 \\
\hline Sugar and jaggery & 76.0 & 88.55 \\
\hline
\end{tabular}

Table.5 Average nutrient intake of the selected elderly from different food habits

\begin{tabular}{|c|c|c|c|}
\hline Nutrient & $\begin{array}{c}\text { Vegetarian } \\
(\text { Mean } \mathbf{\pm S D}) \\
(\mathbf{n = 3 7 5})\end{array}$ & $\begin{array}{c}\text { Non vegetarian } \\
(\text { Mean } \mathbf{\pm S D}) \\
(\mathbf{n = 2 2 5})\end{array}$ & $\mathbf{Z}$ value \\
\hline Protein $(\mathbf{g m})$ & $35.11 \pm 11.97$ & $29.74 \pm 9.95$ & $5.96^{* *}$ \\
\hline Carbohydrate $(\mathbf{g m})$ & $217.46 \pm 67.43$ & $189.63 \pm 56.39$ & $5.43^{* *}$ \\
\hline Fat $(\mathbf{g m})$ & $22.70 \pm 10.18$ & $16.01 \pm 7.66$ & $9.29^{* *}$ \\
\hline Energy (Kcal) & $1227.23 \pm 397.35$ & $1026.97 \pm 324.08$ & $6.72^{* *}$ \\
\hline Iron (mg) & $12.82 \pm 6.49$ & $10.43 \pm 5.10$ & $5.19^{* *}$ \\
\hline Calcium (mg) & $336.10 \pm 182.61$ & $215.55 \pm 145.91$ & $8.90^{* *}$ \\
\hline Phosphorus (mg) & $794.38 \pm 312.28$ & $651.73 \pm 265.19$ & $5.96^{* *}$ \\
\hline Vitamin C (mg) & $28.47 \pm 26.13$ & $16.59 \pm 18.50$ & $6.52^{* *}$ \\
\hline
\end{tabular}

**-Significant at $1 \%$ 
Table.6 Percent adequacy of nutrient intake of the selected elderly from different food habits

\begin{tabular}{|c|c|c|}
\hline Nutrient & $\begin{array}{c}\text { Vegetarian } \\
(\mathbf{n = 3 7 5 )}\end{array}$ & $\begin{array}{c}\text { Non vegetarian } \\
(\mathbf{n = 2 2 5})\end{array}$ \\
\hline Protein (gm) & 64.83 & 53.61 \\
\hline Carbohydrate (gm) & 59.54 & 50.24 \\
\hline Fat (gm) & 112.84 & 79.68 \\
\hline Energy (Kcal) & 65.60 & 54.32 \\
\hline Iron (mg) & 43.86 & 36.22 \\
\hline Calcium (mg) & 41.63 & 26.95 \\
\hline Phosphorus (mg) & 98.76 & 81.47 \\
\hline Vitamin C(mg) & 70.48 & 41.01 \\
\hline
\end{tabular}

Percent adequacy of protein, carbohydrate, fat and energy among vegetarian elderly was 64.83, 59.54, 112.84 and 65.60 percent. While percent adequacy of iron, calcium, phosphorus and vitamin c were 43.86, 41.63, 98.76 and 70.48 percent respectively.

However, highest percent adequacy was noted among vegetarian elderly for fat $(112.84 \%)$ and lowest percent adequacy was noted among non vegetarian elderly for calcium $(26.95 \%)$. As the consumption of non vegetarian foods are rare by non vegetarian elderly, nutritional values were shown lower.

It can be concluded from the result that, the highest values for almost all the anthropometric measurements were noted in urban non-vegetarian elderly subjects. More percent of vegetarian elderly subjects were overweight than non vegetarian elderly.

Selected vegetarian elderly subjects were consuming significantly more cereals $(230.88 \pm 81.50$ gm.) than non-vegetarian elderly subjects $(198.25 \pm 68.29$ gm.). Highest percent adequacy was noted for sugar and jaggery in both groups. Intake of different nutrients was found to be more among vegetarian elderly. Percent adequacy of all the nutrients was found to be lowest in non vegetarian elderly subjects as compared to vegetarian elderly.

\section{References}

Gopalan, C., Ramashastri, B. V. and Balasubramanin, S. C. (2004). Nutritive Value of Indian Foods. NIN, ICMR.

Jellife, D.B. (1966) The assessment of nutritional status of the community. WHO monograph series, N. 53: 236254.

Garcia, S. S., Pena, C. G., Lopez, M. X. D., Cedillo, T. J., Nunez, A. R. C. and Beaman, S. R. (2007). Anthropometric measures and nutritional staus in a healthy elderly population.BMC Public Health. 7(2):1-9.

Gandhi, S.J., Choudary, M.K., Kumar, R. and Bhatnagar, D. (2018). Nutritional status of the geriatric population in the field practice area of a medical college in Rajasthan. Inter. J. community medicine and public health. 5(1): $220-$ 224.

Pai, M. K. (2011). Comparative Study of nutritional status of elderly population living in the home for aged Vs those living in the Community. Biomed. Res. 22(1): 120-126. 
How to cite this article:

Varsha Zanvar and Madhuri Revanwar. 2019. Consumption Pattern of Selected Elderly. Int.J.Curr.Microbiol.App.Sci. 8(12): 1555-1561. doi: https://doi.org/10.20546/ijcmas.2019.812.186 